\title{
FAMILY THERAPY IS EFFECTIVE TO ENHANCE FAMILY SELF-SUFFICIENCY TO CARE FOR ELDERLY FAMILY MEMBERS WITH HYPERTENSION
}

\author{
Asep Iskandar, Koernia Nanda Pratama, Rahmi Setiyani
}

Nursing Program, Universitas Jenderal Soedirman

\begin{abstract}
Hypertension is a one of the most common medical problems affecting the elderly. Strategies to manage the problem is already developed. However, patient's compliance, particularly elderly, to follow hypertension management is considered low. Some factors contributed to patient's non-compliance behaviour are including lack of motivation and family support. Lack of family support was associated to lack of family self-sufficiency for hypertension management. This study aimed at determines the effect of family therapy on family self-sufficiency in managing hypertension. This study used quasy experimental study with control group design. A total of 40 families which divided into two groups (treatment group and control group) were involved in this study. Samples in each group (20 families each) were assigned using simple random sampling technique. Level of family self-sufficiency was determined using Indonesian Ministry of Health definition. Data was analyzed using Wilcoxon test. Result showed that there was a significant difference in family self sufficiency level before and after intervention $(p=0.000)$. Thus, it can be concluded that family therapy is effective to enhance family selfsufficiency to care for elderly family member with hypertension.
\end{abstract}

Key words: Elderly, family therapy, family self-sufficiency, hypertension

\section{ABSTRAK}

Penyakit hipertensi merupakan salah satu masalah kesehatan yang paling sering dialami oleh lansia. Pengendalian hipertensi pada lansia telah dikembangkan. Namun demikian, kepatuhan pasien, khususnya lansia, untuk mengelola hipertensi masih rendah. Ada berbagai faktor yang menyebabkan hal tersebut, termasuk kurangnya motivasi dan dukungan keluarga. Kurangnya dukungan keluarga berhubungan dengan kurangnya kemampuan keluarga dalam pengelolaan hipertensi. Penelitian ini bertujuan untuk melihat efektivitas terapi keluarga terhadap kemandirian keluarga dalam pengelolaan hipertensi. Penelitian ini merupakan penelitian kuantitatif dengan desain kuasi eksperimen menggunakan kelompok kontrol. Sampel penelitian sejumlah 40 keluarga dengan lansia hipertensi yang terbagi atas 2 kelompok yaitu kelompok intervensi yang diberikan terapi keluarga dan kelompok kontrol dengan intervensi standar. Pembagian sampel dilakukan secara acak sederhana. Tingkat kemandirian keluarga diukur menggunakan definisi dari Kementerian Kesehatan RI. Data dianalisa menggunakan uji Wilcoxon. Hasil uji menunjukkan adanya perbedaan tingkat kemandirian keluarga dalam pengelolaan hipertensi lansia sebelum dan sesudah dilakukan intervensi terapi keluarga $(p=0.000)$. Penelitian ini menunjukan bahwa terapi keluarga efektif untuk meningkatkan kemandirian keluarga dalam pengelolaan hipertensi pada lansia.

Kata Kunci: Lansia, terapi keluarga, kemandirian keluarga, hipertensi 


\section{BACKGROUND}

Hypertension is a major health problem due to its high prevalence. In 2013, approximately $26.5 \%$ of Indonesian population suffered from hypertension. This number increased up to $37 \%$ in 2015 and is projected to reach $42 \%$ in 2025 . Moreover, about $63.2 \%$ hypertension case goes undiagnosed due to lack of selfawareness of the individuals to check their blood pressure regularly (Badan Penelitian dan Pengembangan Kesehatan, 2013).

Prevalence of hypertension in Central Java Province is about $26.4 \%$ of its population. This puts Central Java in rank number 10 among provinces with the highest rate of hypertension. Whereas, majority of hypertension case in this province goes undiagnosed. Only $9 \%$ of individuals with hypertension were diagnosed by health professionals (Riset Kesehatan Dasar, 2013). Data from Dinas Kesehatan Kabupaten Banyumas showed that in 2014, there were 8.394 cases of primary hypertension and 1.623 of other type of hypertension in Banyumas district. Hypertension is defined as a systolic blood pressure of $140 \mathrm{mmHg}$ or more, or a diastolic blood pressure of $90 \mathrm{mmHg}$ or more (WHO in Smeltzer and Bare, 2008). The normal range for sistolic blood pressure is $120-140 \mathrm{mmHg}$ and diastolik blood pressure is $80-90 \mathrm{mmHg}$. High blood pressure in elderly is often caused by physiologic changes in cardiovascular system. Vascular wall thickened and losses its elasticity as a result of aging process. However, other factors such as dietary behavior and life style also play important role in increasing risk for hypertension in later life. Consuming highsodium food, high fat food, caffeine contained drink and lack of physical activity has been identified to be the risk factors for hypertension.

Uncontrolled hypertension could lead to complications such as stroke, myocardial infarction, chronic kidney disease, and death. Thus, it is important to lower high blood pressure and protect important organs. Treatment of hypertension comes in many forms, from controling the risk factors to medication. Individuals with hypertension need to changes their life style, such as eating healthy diet and doing physical activities. They also need to check their blood pressure regularly and take medication if necessary.

However, many of hypertensive patients, particularly older adults, do not adhere with the treatment. The noncompliance behavior mostly due to feeling tired of following restrictive diet or taking medication. This problem is often found in chronic condition like hypertension or chronic diseases where the sufferers should maintain certain behavior or life style for a long period of time.

In Indonesia, elderly usually live in three generation family, along with their adult/ married children and grandchildren. Family members mainly spouse and adult children play important role in supporting the elderly, including things related to healthcare needs (Abikusno, 2009). Continuous family support is expected necessary to maintain elderly's health, including their adherence to the treatment when they have disease. In a qualitative study by Barreto and Marcon (2014) among patients with hypertension, they found that some patients believed that the family was a facilitating agent of adherence to treatment by encouraging self-care practices Family members should actively participate in the treatment process. Preparing the suggested meal, encouraging exercise, and developing beneficial leisure time activities are kind of supports that family can give to the elderly family member with hypertension. To give the continuous support to sick family members, the family should be selfsufficient.

Previous research has been identified strategies to develop family selfsufficiency. Konradsdottir and Erla (2011) found that education and family support intervention program improved family competence to care for family member with diabetes. Another intervention to improve family competence or selfsufficiency for managing treatment is family therapy. Family therapy aims at identify problems within the family, and then discuss and solve them with the help of all family members. This intervention 
sets target to improve interaction pattern within the family, so they can solve problems in a better ways. Susanto (2010) found that family therapy intervention that comes in forms of health education and counseling for developing effective communication was effective to improve family self-sufficiency to manage adolescence related problems.

Preliminary survey at Kemutug Kidul Village in 2017 showed that there were 145 people living with hypertension. In interview session, the local health cadres said that the most common condition/ diseases affecting the elderly were hypertension. There was lack of family support for the elderly family members with hypertension, for example elderly often missed the monthly blood pressure check in Posyandu Lansia because no family member could accompany them go to the site. Besides, there was lack of family competence to manage hypertension. The purpose of this study is to determine the effectiveness of family therapy on family self-sufficiency in managing elderly family member with hypertension.

\section{METHODS}

This study used quasy experimental design with control group. A total of 40 families who have elderly family members with hypertension involved in this study. These 40 families were assigned into two groups, intervention or control group, using simple random sampling technique. Intervention group were given family therapy which consists of health education and counseling once a week for 4 weeks. The intervention was given for each family at their own home. Meanwhile, control group received standard therapy that was health education in group. This research has gained the ethical clearance from Ethic Committee Board of Faculty of Medicine Universitas Negeri Solo-RSUD Dr. Moewardi No.220/II/HREC/2018.

Family self-sufficiency was measured using criteria from Indonesian Ministry of Health before and after intervention of family therapy in intervention group (pre-post), and also before and after standard therapy in control group (pre-post). There are 7 competences measured to determine family self-sufficiency. The competences are ranked from very basic skill to advance one, as follows: 1) accepting health professionals; 2) accepting care plan as suggested by the health care team; 3 ) understanding of health problem; 4) using health care facilities; 5) implementing simple care intervention as suggested by health professionals; 6) implementing disease prevention program actively; and 7) implementing health promotion program actively.

Family self-sufficiency is classified into 4 levels, level I until level IV according to competences shown by the family. Families are classified into level I of family-self-sufficiency if they show the first 2 competences; level II if they show the first 5 competences; and level III if they had the first 6 competences. Families are classified into the highest level of family sufficiency or level IV, if they have all those 7 competences.

Demographic characteristic data was measured once at first contact, while family self-sufficiency was measured twice, before and after intervention. Data was then analyzed using univariate and bivariate analysis (Wilcoxon test) (Sopiyudin, 2012).

\section{RESULTS}

This study investigated the effect of family therapy to family self-sufficiency to manage elderly family members with hypertension.

a. Characteristics of respondents

Table 4.1 Characteristics of respondents

\begin{tabular}{lllll}
\hline \multirow{2}{*}{ Characteristics } & \multicolumn{2}{l}{ Intervention } & \multicolumn{2}{l}{ Control } \\
\cline { 2 - 5 } & $\mathbf{f}$ & $\%$ & $\mathbf{f}$ & $\%$ \\
\hline Age (Mean, SD) & 46,15 & 16,65 & 34,9 & 14,63 \\
Gender & & & & \\
$\quad$ Male & 7 & 35 & 6 & 30 \\
$\quad$ Female & 13 & 65 & 14 & 70 \\
Job & & & & \\
$\quad$ Housewife & 11 & 55 & 12 & 60 \\
Farmer & 4 & 20 & - & - \\
$\quad$ Laborer & 1 & 5 & 6 & 30 \\
$\quad \begin{array}{l}\text { Street vendor/ } \\
\text { entrepreneur }\end{array}$ & 4 & 20 & 2 & 10 \\
Education & & & & \\
\hline
\end{tabular}




\begin{tabular}{|c|c|c|c|c|}
\hline \multirow{2}{*}{ Characteristics } & \multicolumn{2}{|c|}{ Intervention } & \multicolumn{2}{|c|}{ Control } \\
\hline & $f$ & $\%$ & $f$ & $\%$ \\
\hline Uneducated & 3 & 15 & - & - \\
\hline $\begin{array}{l}\text { Elementary } \\
\text { School }\end{array}$ & 13 & 65 & 14 & 70 \\
\hline $\begin{array}{l}\text { Junior High } \\
\text { School }\end{array}$ & 3 & 15 & 3 & 15 \\
\hline $\begin{array}{l}\text { Senior High } \\
\text { School }\end{array}$ & 1 & 5 & 3 & 15 \\
\hline \multicolumn{5}{|l|}{ Income } \\
\hline $\begin{array}{l}\text { Less than } \\
\text { standard }\end{array}$ & 18 & 90 & 13 & 65 \\
\hline $\begin{array}{l}\text { More than } \\
\text { standard }\end{array}$ & 2 & 10 & 7 & 35 \\
\hline \multicolumn{5}{|l|}{$\begin{array}{l}\text { Relationship } \\
\text { with elderly }\end{array}$} \\
\hline Son/ daughter & 11 & 55 & 18 & 90 \\
\hline $\begin{array}{l}\text { Son/ daughter } \\
\text { in law }\end{array}$ & 2 & 10 & & \\
\hline Grandchildren & 1 & 5 & 1 & 5 \\
\hline Others & 6 & 30 & 1 & 5 \\
\hline \multicolumn{5}{|l|}{$\begin{array}{l}\text { Living at the } \\
\text { same place with } \\
\text { elderly? }\end{array}$} \\
\hline Yes & 18 & 90,0 & 14 & 70 \\
\hline No & 2 & 10,0 & 6 & 30 \\
\hline
\end{tabular}

Table 4.1 showed that mean age of respondents in intervention group was 46.15 years old and those in control group was 34.9 years old. More than two third of respondents was female. Occupation of the respondents was quite various, but more than half of them were housewives. In regards to education level, majority of respondents in both group were graduated from elementary school. Majority of respondents in intervention group had monthly income less than regional standard (UMR), while in control group were about $65 \%$. In control group, majority of respondents were son/ daughter of the elderly and in intervention group, it was only about $55 \%$. Majority of respondents lived in the same house with the elderly.

b. Family self-sufficiency level in intervention $(n=20)$ and control group $(\mathrm{n}=20)$

Tabel 4.2 Family self-sufficiency level in both groups

\begin{tabular}{lllll}
\hline Self- & \multicolumn{4}{l}{ Intervention, f $(\%)$ Control, f (\%) } \\
sufficiency & Pre & Post & Pre & Post \\
\hline Level I & $16(80)$ & $1(5)$ & $17(85)$ & $14(70)$ \\
Level II & $4(20)$ & $10(50)$ & $3(15)$ & $5(25)$ \\
Level III & - & $8(40)$ & - & $1(5)$ \\
Level IV & - & $1(5)$ & - & - \\
\hline
\end{tabular}

Table 4.2 showed family selfsufficiency level in both group before and after intervention. In initial measurement (pre-test), both group showed similarity in family self-sufficiency level. Majority of the families in both groups were at level I (80\% in intervention group and $85 \%$ in control group). Only few of them were at level II (20\% in intervention group and $25 \%$ in control group). Then, respondents in intervention group were given family therapy for 4 weeks, while those in control group were given standard therapy. After that, level of family self-sufficiency in both groups was re-measured. Result showed that there was slight difference between groups in second measurement (posttest). Majority of families in intervention group were at level II or III (50\% and $40 \%$ respectively), even there was one family reached level IV. Meanwhile, majority of families in control group stayed at level I (70\%). Only few of them moved to level II or higher after given standard health education.

Table 4.3 Bivariate analysis

\begin{tabular}{lllll} 
Variable & $\begin{array}{l}\text { Mean } \\
\text { Rank }\end{array}$ & $\begin{array}{l}\text { Sum of } \\
\text { Ranks }\end{array}$ & $\mathbf{Z}$ & $\begin{array}{l}\text { Asymp. Sig } \\
(\mathbf{2} \text { tailed) }\end{array}$ \\
\hline $\begin{array}{l}\text { Pre-Post in intervention group (family therapy } \\
\text { group) }\end{array}$ & 9,50 & 171 & $-3,866$ & 0.000 \\
Pre-Post in control group (standard therapy) & 2,00 & 6,00 & $-1,633$ & 0,102 \\
\hline
\end{tabular}

Table 4.3 showed bivariate analysis to compare family self-sufficiency level before and after intervention in both groups using Wilcoxon test. Statistical test showed that there was significant difference in family self-sufficiency level before and after given family therapy in intervention group $(p=0.000)$. Meanwhile, control group didn't showed significant differences in family self-sufficiency level after given standard treatment $(p=0.102)$. 
It means that family therapy was effective to improve family self-sufficiency.

\section{DISCUSSION}

This research investigated family self-sufficiency to manage elderly family member with hypertension and determined whether family therapy could improve it. Family self-sufficiency is a term used to describe family's capability to take actions for optimal health function. To achieve this, family should be empowered so they could have self-determination to improve health or manage disease of the entire family member (Nurhaeni, 2011).

Family self-sufficiency is categorized into 4 levels based on competences shown by the family to manage health of their members. This research found that majority of the families in both groups were at level I, which means that the families just have shown two out of seven competences. The first is accepting health professionals. In this case, this competence was shown when family eagerly accepted research team who then gave family therapy for intervention group or standard health education for control group. The second competence is accepting care plan as suggested by health professional. The families in this research were considered having this competence because their elderly family members who suffered from hypertension have already done regular monthly blood pressure checking.

Second measurement of family self-sufficiency level was performed after family therapy intervention in intervention group and standard health education in control group. There was slight difference of the result between groups at the second measurement. Majority of families in intervention group were at level II and III. Meanwhile, majority of families in control group were still at level I.

Families at level II means that they have shown other three competences beside the first two competences previously described. Those three competences are as follows: knowing of health problem, using health care facilities and implementing simple care intervention as suggested by health professionals. In this research, knowing of health problems means that families have identified and explained about hypertension correctly. After given family therapy, half of families in intervention groups could mention the definition, risk factors, complication and few strategies to manage hypertension. Families at level II also have started using health care facilities to get treatment for hypertension, such as primary care facilities, hospital, general practitioners service and nursing care facilities. Strategies to manage hypertension as suggested by health professional such as limiting natrium intake, managing stress, consuming herbal medicine and doing physical activities have been implemented by the family.

Almost half of families in intervention group after family therapy intervention reached level III, but very few families in control group were at this level after given standard treatment. Another competence shown by those in this level was implementing disease prevention program. Whilst families in level I and II only focused to sick individual, those in level III and above paid attention to healthy family members too. In this research, families in level III treated elderly family members with hypertension. However, they also did strategies to prevent other health family members from hypertension at the same time, for example increasing fruit and vegetables intake, searching for information related to hypertension, and taking part in health education program.

This research also found that a family in intervention group moved to level IV after received family therapy. Families at level IV or the highest level of selfsufficiency means that they have accomplished all the competencies. They cared for family members who suffer from hypertension and also implemented disease prevention and health promotion strategies for healthy ones. Family at this level has been able to do all those things independently and has developed awareness to take health promotion action for all family members. Health promotion strategies to prevent hypertension included routine physical exercise, 
smoking cessation, and taking part in health education session.

Important finding from this research was family therapy found to be effective to improve family self-sufficiency to care for elderly family member with hypertension compared to standard health education. This finding supported previous research in area of family therapy and family self-sufficiency. Susanto (2010) did a research to prove the effectivity of family therapy to improve family self-sufficiency in managing reproductive health problems in adolescent. Family therapy in that research was given through several activities, including health education, coaching and counseling. Following family therapy, there were significant life skills improvement among adolescents and effective communication skills among parents. Those skills were important to maintain family self-sufficiency dealing with adolescent's reproductive health problems. Similarly, a study by Shen et al. (2017) revealed that the family memberbased supervised therapy may have positive effects on patients' adherence to blood monitoring and hypertensive medications.

This research used similar method of family therapy as used by Susanto (2010) which combining health education, coaching and counseling. Through health education, family gains knowledge about health and strategies to maintain it. Stuart and Laraia (2005) stated that health education could improve cognitive level of the family because they got new perspective about certain health problem and its related skills, which are necessary for the family to manage it. Besides that, participating in health education also means gaining support from outside the family system. In this research, at the first measurement, families stated that they didn't know much about hypertension. All they knew was hypertension is just when someone has high blood pressure. However, following family therapy, family gained better understanding of hypertension, not only about definition, but also about the signs and symptoms, risk factors, and complication. Moreover, the family also learned new skills for managing hypertension, including monthly blood pressure checking, limiting salt intake, managing stress and doing physical activity.

Counseling as part of family therapy helps family developing effective communication between the members. Effective communication within the family is important for problem solving process, so that all family members would be satisfied with the result. Besides that, counseling makes family feels motivated to care for all the members. Palestin, 2002 in Nugraini (2009) concluded that therapeutic communication to the family with diabetes significantly improved their knowledge level. A review concluded that enhancing family relationships and developing family-strengthening activities appears to be effective on several physical and mental health outcomes, in multiple diseases, across the human lifespan (Garcia-Huidobro \& Mendenhall, 2015).

$$
\text { In this research, counseling }
$$

helped family to have better communication between the members regarding hypertension management, for example limiting natrium intake. In this research, most of elderly in lived with their adult children and got help in some daily activities from the children, including preparing meals. If there was not good communication between elderly and their children, it would be difficult for the elderly to have suggested diet for hypertension since they could not prepare it by themselves. Good communication within the family was also important to reduce stress in elderly family members. Ineffective communication could lead to ineffective problem solving process which often becomes stressor for the elderly. This often happens in extended type of family when different generations that live at the same house possibly have different perspective on the same situation. When elderly faces stressful situation at their surroundings, it could lead to increasing blood pressure.

Standard health education given in control group did not show significant contribution to family self- sufficiency possibly related to lack of family 
involvement. So, even though they have already received much information about hypertension and its management, they might face constraint to implement it daily life. There was limitation in this study. Family self-sufficiency was only measured using instrument, without observation.

\section{CONCLUSION}

Family therapy is effective to enhance family self-sufficiency to care for elderly family member with hypertension. Nurses can use this therapy as one of strategies to manage hypertension in elderly. However, nurses should also pay attention to few factors could possibly influence family self-sufficiency such as education level and economic status of the family.

\section{REFERENCES}

Abikusno, N. (2009). Evaluation and implementation of ageing-related policies in Indonesia. In EN. Arifin \& A. Ananta (Eds), Older persons in Southeast Asia: An emerging assets. Singapore: ISEAS.

Badan Penelitian dan Pengembangan Kesehatan. (2013). Riset Kesehatan dasar (RISKESDAS) 2013. Laporan Nasional 2013.

Barreto, M. S \& Marcon, S. S. (2014). Patient's perspectives on family participation in the treatment of hypertension. Text Context Nursing, Florianópolis, 23(1), 38-46.

Dinas Kesehatan Kabupaten Banyumas. (2014). Profil kesehatan Kabupaten Banyumas Tahun 2014.

Garcia-Huidobro, D. \& Mendenhall, T. (2015). Family oriented care: opportunities for health promotion and disease prevention. Journal of Family Medicine and Disease Prevention, 1(2), 1-6.

Konradsdottir, E \& Erla, K.S. (2011). How effective is a short-term education and support intervention for families of an adolescent with type 1 diabetes?. Iceland: Journal for Specialist in Pediatric Nursing 16, 295-304.

Nugraini, R. (2009). Ganbaran peran keluarga terhadap pengendalian kondisi penderita diabetes melitus di Desa Rejasari Kecamatan Purwokerto Barat Kabupaten Banyumas, Purwokerto. Skripsi. Universitas Jenderal Soedirman.

Nurhaeni, N., Sutadi, H., Rustina Y., \& Supriyatno, B. (2011). Pemberdayaan keluarga pada anak balita pneumonia di rumah sakit: persepsi perawat, anak, dan keluarga. Makara kesehatan, 15 (2), 58-64

Shen, Y., Peng, X., Wang, M., Zeng, X., Xu, J., Lü, L.,...Wang, J. (2017). Family member-based supervision of patients with hypertension: a cluster randomized trial in rural China. Journal of Human Hypertension, 31, 29-36.

Smeltzer, S. C., \& Bare, B. G. (2008). Buku Ajar Keperawatan MedikalBedah Brunner \& Suddarth. Jakarta: EGC.

Sopiyudin, D. (2012). Statistik untuk kedokteran dan kesehatan: deskriptif, bivariat dan multivariat (5th ed.). Jakarta: Salemba Medika.

Sustraini, L, dkk. (2005). Hipertensi. Jakarta: PT Gramedia Pustaka Utama.

Susanto, T. (2010). Pengaruh terapi keperawatan keluarga dengan permasalahan kesehatan reproduksi pada remaja di Kelurahan Ratujaya Kecamatan Pancoran Mas Kota Depok. Malang: Jurnal Keperawatan ejournal.umm.ac.id

Stuart, G. \& Lararia, M.S. (2005). The principle and practice of psychiatric nursing. St, Louis Missouri: Elsevier Morby 